\title{
HTLV-1 in pregnant women from the Southern Bahia, Brazil: a neglected condition despite the high prevalence
}

Marco Antônio Gomes Mello ${ }^{1,2}$, Aline Ferreira da Conceição ${ }^{3}$, Sandra Mara Bispo Sousa ${ }^{4}$, Luiz Carlos Alcântara ${ }^{5}$, Lauro Juliano Marin ${ }^{3}$, Mônica Regina da Silva Raiol ${ }^{3}$, Ney Boa-Sorte ${ }^{6}$, Lucas Pereira Souza Santos ${ }^{3}$, Maria da Conceição Chagas de Almeida7, Tâmara Coutinho Galvão³, Raquel Gois Bastos ${ }^{3}$, Noilson Lázaro 1,6, Bernardo Galvão-Castro ${ }^{1,6}$ and Sandra Rocha Gadelha ${ }^{3 *}$

\begin{abstract}
Background: As the most frequent pathway of vertical transmission of HTLV-1 is breast-feeding, and considering the higher prevalence in women, it is very important to perform screening examinations for anti-HTLV-1 antibodies as part of routine prenatal care. So far, no studies of HTLV-1 seroprevalence in pregnant women in the Southern region of Bahia, Brazil, have been described.

Methods: Pregnant women were selected at the two regional reference centers for health care from Southern Bahia. A total of 2766 pregnant women attending the antenatal unit between November 2008 and May 2010 have been analyzed. An extra blood sample was drawn during their routine antenatal testing. A standardized questionnaire was applied and all positive plasma samples were tested by ELISA and were confirmed by Western Blot and PCR. Besides that, positive women were contacted and visited. The family members that were present during the visit were asked to be serologically screened to the virus. A prospective study was also carried out and newborns were followed up to two years for evaluation of vertical transmission.

Results: HTLV prevalence was 1.05\% (Cl 95\%: 0.70-1.50). There was no association of HTLV-1 infection with age, education, income and ethnic differences. The association with marital status was borderline $(\mathrm{OR}=7.99 ; 95 \% \mathrm{Cl}$ 1.07-59.3; $p=0.042$ ). In addition, 43 family members of the HTLV-1 seropositive women have been analyzed and specific reactivity was observed in $32.56 \%$, including two children from previous pregnancy.

Conclusion: It is very important to emphasize that the lack of HTLV-1 screening in pregnant women can promote HTLV transmission especially in endemic areas. HTLV screening in this vulnerable population and the promotion of bottle-feeding for children of seropositive mothers could be important cost-effective methods to limit the vertical transmission. Besides that, our data reinforce the need to establish strategies of active surveillance in household and family contacts as important epidemiological surveillance actions for the early detection of virus infection and the prevention of transmission by sexual or and parenteral contact.
\end{abstract}

Keywords: HTLV, Bahia-Brazil, Vertical transmission, Pregnant, Prenatal care

\footnotetext{
* Correspondence: sandragadelha@hotmail.com

${ }^{3}$ Universidade Estadual de Santa Cruz, Rodovia Ilhéus-Itabuna Km

16-Salobrinho, Ilhéus, Bahia, Brazil

Full list of author information is available at the end of the article
} reproduction in any medium, provided the original work is properly cited. The Creative Commons Public Domain Dedication waiver (http://creativecommons.org/publicdomain/zero/1.0/) applies to the data made available in this article, unless otherwise stated. 


\section{Background}

It has recently been estimated that about 5 to 10 million people can be infected worldwide with HTLV [1]. However, as many regions in the world have no data, this value can be underestimated. Nevertheless, Brazil is undoubtedly an endemic area for this virus despite the fact that the worldwide distribution is not homogeneous [2] depending upon the geographic region and the analyzed group [3]. Salvador/ Bahia is an area of important prevalence, according to two classical studies: one involving blood donors, and that showed that Salvador has the highest prevalence of Brazil (1.36\%) [4] and another involving the overall population from Salvador, which detected a prevalence of $1.76 \%$ (reaching $8.4 \%$ in women aged 51 years or above) [5]. Besides the higher prevalence in women, the virus was associated with lower education and lower income levels [5], as well as areas with the worst indicators of socioeconomic position [6].

HTLV-1 transmission occurs from mother to child, predominantly through breastfeeding, via sexual intercourse, or through transfusion of cellular blood components [7]. The efficiency of HTLV-1 transmission is related to the route of transmission. The parenteral route (by transfusion or needles sharing) is the most efficient route of transmission. The risk of seroconversion after a transfusion may reach $60 \%$ [8]. In the sexual transmission, the infection is more efficient from males to females. In 10 years the risk can be $61 \%$ in this direction and only $0.4 \%$ in the reverse direction, ie, from women to men [9]. In the vertical transmission, the most frequent pathway of HTLV-1 transmission occurs via breastfeeding, and the risk of infection has been correlated with the provirus load in breastmilk, the concordance of HLA class-I type between mother and child, and the duration of breastfeeding [10-12].

The higher prevalence in women and the possibility of mother-to-child transmission reinforce that it is very important to perform screening for anti-HTLV-1 antibodies during prenatal care and take measures to avoid or, at least, to decrease the risks of transmission. In fact, postnatal infection by breastfeeding seems to play the most important role in vertical transmission; thus, seropostive mothers have been counseled to avoid breastfeeding $[13,14]$. In Japan, the refraining of breast-feeding conducted by HTLV-1 positive mothers dramatically reduced vertical transmission [14]. In point of fact, it has been suggested that preventing mother-to-child transmission would probably have the most significant impact on the occurrence of HTLV-1-associated diseases [15]. In addition, different clinical manifestation related to HTLV-1, such as: infective dermatitis (IDH), adult T-cell leukemia/lymphoma (ATL), and HTLV-1associated myelopathy/tropical spastic paraparesis (HAM/ TSP) occur in individuals who have been vertically infected [16-18].
In relation to the rate of HTLV-1 infection in pregnant women from Brazil, the prevalence is diverse and heterogenous. In Salvador, Bahia state, it was found $0.84 \%$ and $0.88 \%[18,19]$, and $0.98 \%$ in the town of Cruz das Almas, which is located in the Recôncavo area, 149 Km west from Salvador (4/408) [20]. Nevertheless, these mentioned prevalences are at least three to ten times higher than in other regions of the country [6,21-23].

Ilhéus and Itabuna are the biggest cities in Southern Bahia and are references in health services, treating people from different cities in this region. So far, no studies concerning HTLV-1 seroprevalence amongst pregnant/puerperal women from Southern Bahia have been described. Also considering the importance of these two cities and the high prevalence of HTLV both in Salvador as in other small and mid-sized cities from Bahia, we have decided to evaluate the frequency of this infection amongst women treated at the antenatal units of the two of the largest regional hospitals-one located in Ilheus and the other in Itabuna. In addition, the clinical and epidemiological data of the HTLV-1 positive women were compared with data from a group of HTLV-1 seronegative women. We have also tested HTLV infection in family members of the seropositive women so as to evaluate the possible routes of transmission.

\section{Results}

A total of 2766 pregnant women treated at the antenatal unit between November 2008 and May 2010 were analyzed. Twenty nine pregnant women (1.05\%; CI 95\%: 0.701.50) were HTLV-1 positive, as confirmed by Western blot and PCR. Five of 2766 pregnant women assessed were positive by ELISA and negative after performing the Western Blot, giving a rate of $0.18 \%$ of false positive. It was verified one co-infection with HIV and no coinfection with Treponema pallidum. Their general prevalences were, respectively, $0.22 \%$ (CI 95\%: 0.08-0.48) and $0.47 \%$ (CI 95\%: 0.52-0.80).

All of the 29 HTLV-1 positives were found to be asymptomatic. As regards the place of residence, the city with more cases was Ilheus $(n=14)$, followed by Itabuna $(n=05)$. Besides, there have been two cases in Itacaré and one case in the following cities: Coaraci, Wenceslau Guimarães, Uruçuca, Itororó, Camamu, Iguaí, Una and Canavieiras. Amongst the HTLV-positive women, 83.3\% reported to be brown, $70.8 \%$ were illiterate, and $69 \%$ said to receive less than 1 minimum Brazilian wage per month. Only one had received a blood transfusion and, importantly, all HTLV-1 positive women who had another child breastfed him/her. Despite the fact that these women were in the pre-partum room, only two of them have been informed to be HTLV-seropositive during the prenatal care. In these cases, women were advised to 
have a cesarean delivery and not to breastfeed. Table 1 presents a bivariate analysis for the association of HTLV-1 infection with demographic and social variables. It was found an association with marital status. Yet, the association was not accurate $(\mathrm{OR}=7.99$; 95\% CI 1.08 59.31; $\mathrm{p}=0.042)$. As for the other variables, no statistically significant association has been detected.

We have been able to visit 21 women, one of which refused to continue in the study. In this opportunity, samples from 43 family members of the HTLV-1 seropositive women have been collected, including: partner $(n=10)$, mother $(n=8)$, father $(n=2)$, sister $(n=2)$, brother $(n=2)$, children of previous pregnancies $(n=15)$ and others $(n=4)$. Specific reactivity was observed in $14 / 43 \quad(\approx 32.6 \%)$ individuals. Among these cases, two were children (1 son and 1 daughter-2.3 and 8 years old, respectively) of previous pregnancies from two HTLV-positive mothers. The other HTLV-seropositives were: 5 mothers, 1 father, 4 partners, 2 sisters (Figure 1). In one case, we had three generations of HTLV-1 infected by the virus (Figure 1). Moreover, half in the evaluated families $(10 / 20)$ had at least one relative HTLV-1 seropositive.

\section{Discussion}

In this study, the overall analyses of 2766 pregnant women revealed a prevalence of $1.05 \%$. Previous studies in endemic areas of Brazil have found a similar prevalence $[19,24]$ demonstrating that Southern Bahia is another region where the virus circulates with a prevalence much higher than in other regions of the country-at least three to ten times higher [6,21-23]. Additionally, this prevalence was much higher than the prevalence of HIV (0.22\%-CI 95\%: 0.08-0.48) and Treponema pallidum (0.47\%-CI 95\%: 0.52-0.80) in the analyzed population. It is noteworthy that prevalence rates for these two microorganisms can still be overestimated, since they were calculated from the results of rapid test for HIV and Venereal Disease Research Laboratory (VDRL) for Treponema pallidum. In the case of HTLV, all samples were subjected to confirmatory tests.

As we are studying a specific group, the results probably do not represent the overall population. However, in a study comparing data from specific populations (injecting drug users, blood donors and pregnant women), Hlela et al., have suggested that blood donors and pregnant women in Southern America and the Caribbean may be more representative of the general population and can therefore be suitable for estimating prevalence in these regions [25]. In fact, even though the prevalence rates in pregnant women do not represent the overall population, they are very important because the virus can be transmitted to children during pregnancy and, most importantly, during the breastfeeding process. Besides that, different clinical manifestations related to HTLV-1, such as: infective dermatitis (IDH), adult T-cell leukemia/lymphoma (ATL), HTLV-1-associated myelopathy/tropical spastic paraparesis (HAM/TSP) occur in individuals who have been vertically infected [16].

Accordingly, it has been suggested that the detection of HTLV infection through prenatal or neonatal screening can be fundamental in sub-areas with high seropositivity rates, permitting to take preventive measures to reduce vertical transmission [6]. A classical study has demonstrated that the refraining of breast-feeding for HTLV-1 positive mothers has dramatically reduced vertical transmission in Japan [14]. Nonetheless, bottle-fed children can also become vertically infected in much lower frequencies. Then, the prenatal detection is more effective for prevention, whereas additional measures such as an elective cesarean in HTLV-positive pregnants can be taken. In a previous study involving fortyone bottle-fed children from Brazil, no case of vertical transmission was observed. In this case, $81.5 \%$ of the children were born by an elective cesarean section and this fact may have contributed to the absence of transmission [26].

In relation of the route of transmission, it was suggested that, in Salvador, the infections have been acquired via breastfeeding, and, in second place, sexually. In this study, the analysis of HTLV-1 serology in relatives, partners and children of previous pregnancies of the index case (pregnant) has revealed HTLV-1 positive cases in different family members, highlighting partners, mothers and children ( 1 son and 1 daughter-2.3 and 8 years old, respectively). Therefore, it can be assumed that the virus infection in Southern Bahia can be spread both sexually and vertically. In fact, both routes of transmission have been related to HTLV in endemic areas [26]. In addition, it is noteworthy that the two mentioned HTLV-positive children were breastfed. In this study, all of the HTLV-positive women contacted were advised not to breastfeed and the newborns were followed up to two years. Until that time, no positive case has been detected by PCR. Nonetheless, it has been argued that it is necessary to keep in mind that, in developed countries, the advice of not breastfeeding should be made carefully, because the health risk of early weaning can be higher than the risks of HTLV-1 related diseases [27].

Still on the familial transmission, it should be emphasized that half the evaluated families had at least a HTLV-seropositive member. Besides that, the analysis of infection rates in family members indicated a seropositive rate of $32.55 \%(14 / 43)$. This number is higher than that recently found in a survey evaluating familial transmission [28] in Pará state (25.2\%), another endemic area 
Table 1 Analysis for HTLV-1 positive and HTLV-1 negative pregnant women

\begin{tabular}{|c|c|c|c|c|}
\hline Variable & HTLV-positive N (\%) & HTLV-negative N (\%) & Odds ratio & 95\% Confidence interval \\
\hline \multicolumn{5}{|l|}{ Age (years) } \\
\hline $9-19$ & $04(16.7)$ & $718(26.3)$ & 1.00 & - \\
\hline $20-29$ & $18(75.0)$ & $1504(55.2)$ & 2.15 & $0.72-6.37$ \\
\hline$>30$ & $02(8.3)$ & $504(18.5)$ & 0.71 & $0.12-3.90$ \\
\hline Total (N) & 24 & 2726 & & \\
\hline \multicolumn{5}{|l|}{ Literacity } \\
\hline Illiterate & $17(70.8)$ & $1771(64.8)$ & 1.30 & $0.55-3.20$ \\
\hline Literate & $07(29.2)$ & $964(35.2)$ & 1.00 & - \\
\hline Total (N) & 24 & 2735 & & \\
\hline \multicolumn{5}{|l|}{ Skin color } \\
\hline White & $02(8.3)$ & $329(12.0)$ & 1.00 & - \\
\hline Black & $02(8.3)$ & $687(25.1)$ & 0.48 & $0.67-3.41$ \\
\hline Brown & $20(83.4)$ & $1623(59.3)$ & 2.02 & $0.47-8.71$ \\
\hline Yellow & No cases & $97(3.6)$ & - & - \\
\hline Total (N) & 24 & 2736 & & \\
\hline \multicolumn{5}{|l|}{ Income* } \\
\hline$<1.0 \mathrm{mw}$ & $20(69.0)$ & $1773(65.2)$ & 0.46 & $0.11-1.85$ \\
\hline $1-2 \mathrm{mw}$ & $03(10.3)$ & $493(18.1)$ & 0.85 & $0.34-2.14$ \\
\hline$>2 \mathrm{mw}$ & $06(20.7)$ & $455(16.7)$ & 1.00 & - \\
\hline Total (N) & 29 & 2721 & & \\
\hline \multicolumn{5}{|l|}{ Marital status } \\
\hline Married & $01(4.2)$ & $706(25.8)$ & 1.00 & - \\
\hline Single/Divorced/Widow & $23(95.8)$ & $2031(74.2)$ & 7.99 & $1.07-59.3$ \\
\hline Total (N) & 24 & 2737 & & \\
\hline \multicolumn{5}{|l|}{ Stable partner } \\
\hline Yes & $18(75.0)$ & $2402(87.8)$ & 1.00 & - \\
\hline No & $06(25.0)$ & $334(12.2)$ & 2.40 & $0.94-6.08$ \\
\hline Total (N) & 24 & 2736 & & \\
\hline \multicolumn{5}{|l|}{ History of blood transfusion } \\
\hline Yes & $01(4.2)$ & $93(3.4)$ & 1.20 & $0.16-9.24$ \\
\hline No & $23(95.8)$ & 2641 (96.6) & 1.00 & - \\
\hline Total (N) & 24 & 2734 & & \\
\hline \multicolumn{5}{|l|}{ Alcohol use } \\
\hline Yes & $04(16.7)$ & $479(17.5)$ & 0.94 & $0.32-2.77$ \\
\hline No & $20(83.3)$ & $2258(82.5)$ & 1.00 & - \\
\hline Total (N) & 24 & 2737 & & \\
\hline \multicolumn{5}{|l|}{ Smoking } \\
\hline Yes & $01(4.2)$ & $164(6.0)$ & 0.68 & $0.91-5.08$ \\
\hline No & $23(95.8)$ & $2573(94.0)$ & 1.00 & - \\
\hline Total (N) & 24 & 2737 & & \\
\hline
\end{tabular}




\begin{tabular}{|c|c|c|c|c|}
\hline \multicolumn{5}{|c|}{ Tattoo or piercing } \\
\hline Yes & $04(16.7)$ & $612(22.4)$ & 0.69 & $0.23-2.03$ \\
\hline No & $20(83.3)$ & $2120(77.6)$ & 1.00 & - \\
\hline Total (N) & 24 & 2732 & & \\
\hline
\end{tabular}

${ }^{*}$ mw, minimum Brazilian wages per month.

for HTLV in Brazil. Without a doubt, the abovementioned data reinforce the need to establish strategies of active surveillance in household and family contacts as an important epidemiological surveillance action aimed at detecting early the virus infection and preventing the transmission by sexual or parenteral way. In effect, it has been shown that the virus spreads silently within families and that there is a familial aggregation of this infection [28].

This study has detected an association with marital status, but it was not precise. Besides, there was no association of HTLV-1 infection with age, education, and income according to what was found by Magalhães et al. [20], in the analysis of pregnant women from a medium sized town in Northern Brazil, unlike the observed in other studies conducted in Salvador, which have found an association between HTLV infection and lower income $[5,17]$. In the way, we have not found any association between the self-reported skin color and HTLV infection. However, it has been recently detected a higher HTLV prevalence in donors with black skin color [29]. In fact, the two groups (HTLV-1 positive and soronegative) analyzed in our study are very similar in terms of social, demographic and ethnic characteristics, according to the population treated at public hospitals of mediumsized Brazilian cities, where the majority of people is subjected to low levels of income and education.

\section{Conclusion}

In summary, these results are very relevant because: (1) no studies of HTLV-1 seroprevalence in pregnant/puerperal women from the Southern region of Bahia had been described so far; (2) Southern Bahia must be another endemic area for the virus, presenting a high prevalence in pregnant women that is much higher than the national average; (3) the HTLV-1 interfamilial transmission is important and to carry out an active case search can be an important strategy in the epidemiological surveillance of this infection; (4) there is no effective treatment to HTLV infection and interventions to prevent vertical transmission

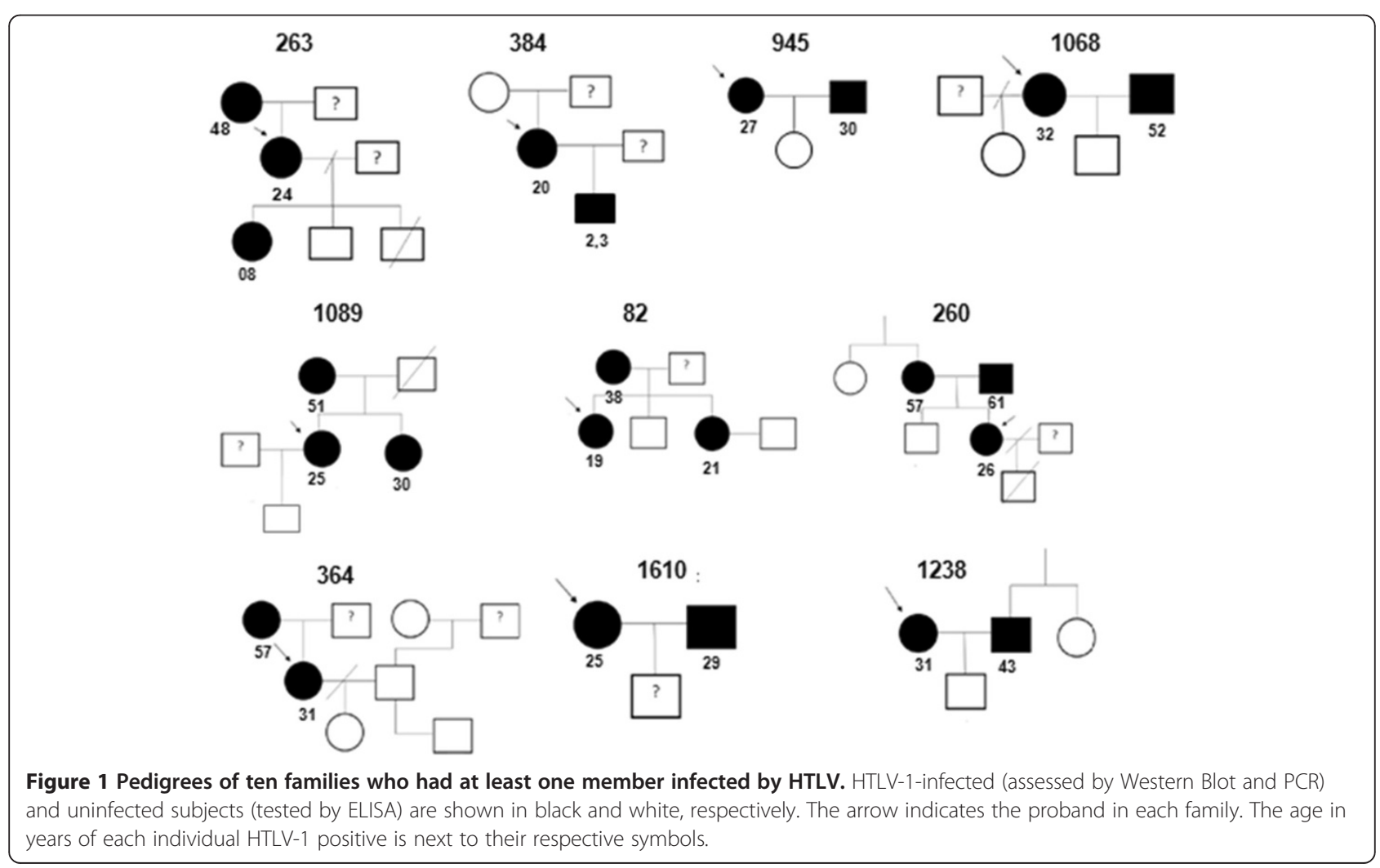


in geographic areas with high prevalence would likely reduce the incidence of mother-to-child transmission and HTLV-related diseases and; (5) last but not least, despite the high prevalence observed in Southern Bahia, it seems that a number of pregnant women treated in the public health system have not been tested to HTLV during the prenatal routine in this region and may have breastfed their babies and could have infected them and spread the infection that reinforce the need for mandatory serological screening in the routine prenatal care of Bahia state.

\section{Methods}

A cross-sectional study involving pregnant women treated at the antenatal units of the two reference health centers from Southern Bahia has been conducted: Maternidade Santa Helena, from Ilhéus, and Hospital Manoel Novaes Santa Casa de Misericórdia, from Itabuna, between November 2008 and May 2010. This macroregion covers 99 cities, totaling more than $1,025,000$ women in childbearing age, and more than 25,000 live births in 2011. The mentioned hospitals treat women from these cities as well as different neighboring cities.

For the study, an extra blood sample was drawn during their routine antenatal (syphilis, HIV, ABO and Rhesus) appointments. A standardized questionnaire has been applied after informed consent to collect the following data: age, formal education, history of smoking, alcohol consumption, blood transfusion, past medical history, current medication, and income level. Furthermore, the medical records were analysed to know the results of two tests: (1) rapid test for HIV and (2) VDRL. It was included in the analyses all women who fulfilled the following criteria: (1) collected blood sample in the antenatal unit; (2) answered the standardized questionnaire; (3) signed the consent informed (in younger than 18 years old, the parents/legal guardians were asked for the permission). The project was approved by the Ethic Committee of Universidade Estadual de Santa Cruz (UESC).

HTLV-1 infection was assessed by ELISA (Ortho HTLV-I/HTLV-II Ab-Capture ELISE Test System). The positive plasma samples were tested repeatedly in duplicate and confirmed by Western blot (HTLV BLOT 2.4Genelab Diagnostic). Besides, the DNA of 29 HTLV-1 positive samples was extracted by QIAgen Kit (QIAamp DNA Blood Kit), followed by a nested-PCR for the Long Terminal Repeat (LTR) region on HTLV-1. Two HTLV-1 overlapping fragments were amplified: a LTR-gag $473 \mathrm{bp}$ and a LTR-tax $479 \mathrm{bp}$, as previously described [30]. HTLV-positive women were contacted by phone and visited by a healthcare team, which included, among other professionals, a pediatrician. In this opportunity, the results and the HTLV condition have been explained, and samples of family members (spouse, partners children or others, considering the known transmission routes for the virus) have been collected after informed consent to analyze HTLV infection and interfamilial transmission. All those who had interest in performing the diagnosis of HTLV were include. For minors, parents or guardians were consulted and should authorize the test. Besides, a prospective study was also carried out and newborns were followed up to two years for evaluation of vertical transmission.

Frequency distributions were determined for each variable. Age was examined in 3 different strata to analyze trends in prevalence (9-19 y; 20-29 y and $30 \mathrm{y}$ or more). The other variables (and no exposure condition) were: education (illiterate or literate), income $(<1.0$ minimum Brazilian wages per month (mw); 1-2 $\mathrm{mw}$ and $>2 \mathrm{mw}$ ), ethnic classification, and marital status (married/with partner or single/Divorced/Widow). Known risk factors (previous blood transfusion, have tattoos and/or piercings) and lifestyle habits have been analyzed (alcohol consumption and smoking). A bivariate analysis was carried out.

Odds Ratio (ORs) and 95\% confidence intervals (95\% CIs) were calculated to measure the association of selected variables with HTLV-1 infection. The statistical package STATA version 10.0 was used for statistical analyses. P-values $<0.05$ were considered significant.

\section{Competing interests}

The authors declare that they have no competing interests.

\section{Authors' contributions}

MAGM: participated in the design of the study, carried out the PCR, carried out the maintenance of the database and helped to draft the manuscript. LPSS, TCG, RGB, AFC: applied the standardized questionnaire, the informed consent and processed the blood samples to perform serology. NBS, MCCA: participated in the design of the study, performed the statistical analysis and helped to draft the manuscript. LCA: participated in the design of the study and helped in the realization of molecular analyzes. BGC: participated in the design of the study, helped to draft the manuscript. LJM, SMBS: participated in the design of the study, helped in identifying positive women, made contact and scheduled the visits, and helped to draft the manuscript. NL: carried out the ELISA and Westen Blot and carried out the blood collection during the visits. MRSR: participated in the design of the study and provided orientation concerning the result of the tests and about breastfeeding during the project. SRG: conceived of the study, coordinated it and drafted the manuscript. All authors read and approved the final manuscript

\section{Acknowledgements}

This study was financially aided by the following institutions: PROPP-UESC, FAPESB and CNPq. The authors are thankful to LASP-FIOCRUZ-Bahia and Fundação Bahiana para Desenvolvimento das Ciências-Escola Bahiana de Medicina e Saúde Pública for the technical and laboratorial support. The authors are also thankful to the staff of Maternidade Santa Helena, from Ilhéus, and Hospital Manoel Novaes Santa Casa de Misericórdia, from Itabuna for their operational support.

\section{Author details}

'LASP/CPqGM/FIOCRUZ, Salvador, Bahia, Brazil. ²Faculdade de Ilhéus, Ilhéus, Bahia, Brazil. ${ }^{3}$ Universidade Estadual de Santa Cruz, Rodovia Ilhéus-Itabuna Km 16-Salobrinho, Ilhéus, Bahia, Brazil. ${ }^{4}$ Universidade Estadual do Sudoeste da Bahia, Vitória da Conquista, Bahia, Brazil. ${ }^{5}$ LHGB/CPqGM/FIOCRUZ,

Salvador, Bahia, Brazil. ${ }^{6}$ Escola Bahiana de Medicina e Saúde Pública, Salvador, Bahia, Brazil. 'LEMB/CPqGM/FIOCRUZ, Salvador, Bahia, Brazil.

Received: 30 October 2013 Accepted: 11 February 2014

Published: 13 February 2014 


\section{References}

1. Gessain A, Cassar O: Epidemiological aspects and world distribution of HTLV-1 infection. Front Microbiol 2012, 3:388.

2. Catalan-Soares B, Carneiro-Proietti ABF, Proietti FA, Interdisciplinary HTLV Research Group: Heterogeneous geographic distribution of human T-cell lymphotropic viruses I and II (HTLV-I/II): serological screening prevalence rates in blood donors from large urban areas in Brazil. Cad Saúde Pública 2005, 21:926-931.

3. Catalan-Soares B, Proietti FA, Carneiro-Proietti ABF: Os vírus linfotrópicos de célulasT humanos (HTLV) na última década (1990-2000). Rev Bras Epidemiol 2001, 4:81-95.

4. Galvao-Castro B, Loures L, Rodriques LG, Sereno A, Ferreira-Junior OC, Franco LG, Muller M, Sampaio-Da-Santana A, Galvao-Castro B, Loures L, Rodriques LG, Sereno A, Ferreira-Junior OC, Franco LG, Muller M, SampaioDa-Santana A, Passos LM, Proietti F: Distribution of human T-lymphotropic virus type I among blood donors: a nationwide Brazilian study. Transfusion 1997, 37:242-243.

5. Dourado I, Alcântara LC, Barreto ML, Teixeira MG, Galvao-Castro B: HTLV-1 in the general population of Salvador, Brazil: a city with African ethnic and sociodemographic characteristics. J Acquir Immune Defic Syndr 2003, 34:527-531.

6. Ribeiro MA, Proietti FA, Martins ML, Januário JN, Ladeira RV, De Oliveira MF Carneiro-Proietti AB: Geographic distribution of human T-lymphotropic virus types 1 and 2 among mothers of newborns tested during neonatal screening, Minas Gerais, Brazil. Rev Panam Salud Publica 2010, 27:330-337.

7. Proietti FA, Carneiro-Proietti ABF, Catalan-Soares BC, Murphy EL: Global epidemiology of HTLV-1 infection and associated diseases. Oncogene 2005, 24:6058-6068

8. Okochi $K$, Sato $H$, Hinuma $Y$ : A retrospective study on transmission of adult $T$ cell leukemia virus by blood transfusion: seroconversion in recipients. Vox Sang 1984, 46:245-253.

9. Kajiyama W, Kashiwagi S, Ikematsu H, Hayashi J, Nomura H, Okochi K: Intrafamilial transmission of adult T-cell leukemia virus. J Infect Dis 1986, 154:851-857.

10. Hisada M, Maloney EM, Sawada T, Miley WJ, Palmer P, Hanchard B, Goedert $J$ J, Manns A: Virus markers associated with vertical transmission of human T lymphotropic virus type 1 in Jamaica. Clin Infect Dis 2002, 34:1551-1557.

11. Biggar RJ, Ng J, Kim N, Hisada M, Li HC, Cranston B, Hanchard B, Maloney EM: Human leukocyte antigen concordance and the transmission risk via breast-feeding of human T cell lymphotropic virus type I. J Infect Dis 2006, 193:277-282.

12. Wiktor SZ, Pate EJ, Rosenberg PS, Barnett M, Palmer P, Medeiros D, Maloney EM, Blattner WA: Mother-to-child transmission of human T-cell lymphotropic virus type I associated with prolonged breast-feeding. J Hum Virol 1997, 1:37-44

13. Carneiro-Proietti AB, Catalan-Soares BC, Castro-Costa CM, Murphy EL, Sabino EC, Hisada M, Galvao-Castro B, Alcantara LC, Remondegui C, Verdonck K, Proietti FA: HTLV in the Americas: challenges and perspectives. Rev Panam Salud Publica 2006, 19:44-53.

14. Hino S, Katamine S, Miyata H, Tsuji Y, Yamabe T, Miyamoto T: Primary prevention of HTLV-1 in Japan. Leukemia 1997, 11:57-59.

15. Ribeiro MA, Martins ML, Teixeira C, Ladeira R, Oliveira Mde F, Januário JN Proietti FA, Carneiro-Proietti AB: Blocking vertical transmission of human T cell lymphotropic virus type 1 and 2 through breastfeeding interruption. virus type 1 and 2 through breastfeeding interruption. Pediatr Infect Dis J 2012, 31(11):1139-1143.

16. Bittencourt AL, Primo J, Oliveira ML: Manifestations of the human T-cell lymphotropic virus type I infection in childhood and adolescence. J Pediatr (Rio J) 2006, 82:411-420.

17. Bittencourt AL, Primo J, Oliveira ML: Dermatite Infecciosa e outras manifestações infato-juvenis associados à infecção pelo HTLV-1. In Cadernos hemominas. XIIlth edition. Edited by Proietti AB. Belo Horizonte: Fundação Centro de Hematologia e Hemoterapia de Minas Gerais; 2006:174-191.

18. Dos Santos Jl, Lopes MA, Deliège-Vasconcelos E, Couto-Fernandez JC, Patel BN, Dos Santos JI, Lopes MA, Deliège-Vasconcelos E, Couto-Fernandez JC, Patel BN, Barreto M, Ferreira Júnior OC, Galvão-Castro B: Seroprevalence of HIV, HTLV-I/II and other perinatally-transmitted pathogens in Salvador, Bahia. Rev Inst Med Trop Sao Paulo 1995, 37:343-348.

19. Bittencourt AL, Dourado I, Filho PB, Santos M, Valadão E, Alcantara LC, Galvão-Castro B: Human T-cell lymphotropic virus type 1 infection among pregnant women in northeastern Brazil. J Acquir Immune Defic Syndr 2001, 26:490-494.
20. Magalhães T, Mota-Miranda AC, Alcantara LC, Olavarria V, Galvão-Castro B, RiosGrassi MF: Phylogenetic and molecular analysis of HTLV-1 isolates from a medium sized town in northern of Brazil: tracing a common origin of the virus from the most endemic city in the country. J Med Virol 2008, 80:2040-2045.

21. Guimarães de Souza V, Lobato Martins M, Carneiro-Proietti AB, Januário JN, Ladeira RV, Silva CM, Pires C, Gomes SC, De Martins CS, Mochel EG: High prevalence of HTLV-1 and 2 viruses in pregnant women in São Luis, state of Maranhão, Brazil. Rev Soc Bras Med Trop 2012, 45:159-162.

22. Dal Fabbro MM, Cunha RV, Bóia MN, Portela P, Botelho CA, Freitas GM, Soares J, Ferri J, Lupion J: HTLV 1/2 infection: prenatal performance as a disease control strategy in State of Mato Grosso do Sul. Rev Soc Bras Med Trop 2008, 41:148-518.

23. Olbrich Neto J, MEIRA DA: Soroprevalence of HTLV-I/II, HIV, siphylis and toxoplasmosis among pregnant women seen at Botucatu-São Paulo-Brazil: risk factors for HTLV-I/II infection. Rev Soc Bras Med Trop 2004, 37:28-32

24. Soares BCC, Castro MSM, Proietti FA: Epidemiologia do HTLV-1/II. In Cadernos hemominas. Xlth edition. Edited by Proietti AB. Belo Horizonte: Fundação Centro de Hematologia e Hemoterapia de Minas Gerais; 2000:53-75.

25. Hela C, Shepperd S, Khumalo NP, Taylor GP: The prevalence of human t-cell lymphotropic virus type 1 in the general population is unknown. Aids Rev 2009, 11:205-214.

26. Bittencourt AL, Sabino EC, Costa MC, Pedroso C, Moreira L: No evidence of vertical transmission of HTLV-I in bottle-fed children. Rev Inst Med Trop Sao Paulo 2002, 44:63-65.

27. van Tienen C, Jakobsen M, van der Schim Loeff M: Stopping breastfeeding to prevent vertical transmission of HTLV-1 in resource-poor settings: beneficial or harmful? Arch Gynecol Obstet 2012, 2012(286):255-256.

28. Da Costa CA, Furtado KC, De Ferreira LS, De Almeida DS, Da Linhares AC, Ishak R, Vallinoto AC, De Lemos JA, Martins LC, Ishikawa EA, De Sousa RC, De Sousa MS: Familial transmission of human T-cell lymphotrophic virus: silent dissemination of an emerging but neglected infection. PLOS Negl Trop Dis 2013, 13:e2272.

29. Carneiro-Proietti AB, Sabino EC, Leão S, Salles NA, Loureiro P, Sarr M, Wright D, Busch M, Proietti FA, Murphy EL, Nhlbi Retrovirus Epidemiology Donor Study-li (Reds-li), International Component: Human T-lymphotropic virus type 1 and type 2 seroprevalence, incidence, and residual transfusion risk among blood donors in Brazil during 2007-2009. AIDS Res Hum Retroviruses 2012, 28:1265-1272.

30. Alcantara LC, Oliveira T, Gordon M, Pybus O, Mascarenhas RE, Seixas MO, Gonçalves M, Hlela C, Cassol S, Galvão-Castro B: Tracing the origin of Brazilian HTLV-1 as determined by analysis of host and viral genes. AIDS 2006, 20:780-782.

\section{doi:10.1186/1743-422X-11-28}

Cite this article as: Mello et al: HTLV-1 in pregnant women from the Southern Bahia, Brazil: a neglected condition despite the high prevalence. Virology Journal 2014 11:28.

\section{Submit your next manuscript to BioMed Central and take full advantage of:}

- Convenient online submission

- Thorough peer review

- No space constraints or color figure charges

- Immediate publication on acceptance

- Inclusion in PubMed, CAS, Scopus and Google Scholar

- Research which is freely available for redistribution

Submit your manuscript at www.biomedcentral.com/submit
C) BioMed Central 